\title{
Impact of Thyme Oil and Lactobacillus acidophilus as Natural Growth Promoters on Performance, Blood Parameters and Immune Status in Growing Rabbits
}

\author{
Ahmed Mohamed El-kaiaty ${ }^{1}$, Gihan Mohamed El-Moghazy ${ }^{2}$, Mohamed Ahmed Fouad El-Manylawi ${ }^{1}$ and \\ Mahmoud Gaber Yousef Abdel-Mageed ${ }^{2} *$
}

${ }^{1}$ Department of Animal Production, Faculty of Agriculture, Cairo University, 12613, Giza, Egypt

${ }^{2}$ Regional Center for Food and Feed, Agricultural Research Center, 12619, Giza, Egypt

*Corresponding author`s Email: ma1990844@yahoo.com ; DoRCiD: 0000-0002-0408-469X

\begin{abstract}
Present study was conducted to evaluate the effect of thyme oil and lactobacillus acidophilus (supplement) as growth promoters in rabbits. 72 weaned V-Line male rabbits were randomly allocated into 4 equal groups. The first group (G1) was without any additives and consider as control group. The second group (G2) treated with the addition of lactobacillus acidophilus in drinking water in a concentration of $10^{8} \mathrm{cfu} / \mathrm{ml}$. The third group (G3) treated with the addition of thyme oil in drinking water in a concentration of $1 \mathrm{ml} /$ liter. The fourth group (G4) treated with the addition of both lactobacillus acidophilus and thyme oil in drinking water in a concentration of $10^{8} \mathrm{cfu} / \mathrm{ml} \mathrm{plus}$ $1 \mathrm{ml} / \mathrm{L}$, respectively. The obtained results showed that, all treatments had significant improvement effects on the measured parameters (performance characteristics, cecum characteristics, RBCs, WBCs, kidney function, triglycerides, total cholesterol, sheep RBC's titer, liver antioxidant markers and hormones markers) when compared to the control group. The live body weight of G3 and G4 groups were higher (2116 and $2058 \mathrm{~g}$ ) than those found in G2 and G1 groups (1958 and $1850 \mathrm{~g}$ ) respectively. In addition, the body weight gain of G3 and G4 groups were higher (1364 and $1307 \mathrm{~g}$ ) than those found in G2 and G1 groups (1207 and $1100 \mathrm{~g}$ ). Moreover, the daily weight gain of G3 and G4 groups were higher (32.49 and $31.13 \mathrm{~g} / \mathrm{d}$ ) than those found in G2 and G1 groups (28.74 and $26.19 \mathrm{~g} / \mathrm{d})$. In addition, feed conversion ratio of G3 and G4 groups were higher (3.41 and 3.61) than those found in G2 and G1 groups (3.66 and 4.67). While G4, G2 and G3 groups had a significant enrichment effect on the intestinal beneficial bacteria. In conclusion, in present experiment inclusion thyme oil and/or lactobacillus acidophilus in the drinking water that stimulated body weight gain and increased feed conversion rate, and can be used as growth promoters in rabbit nutrition successfully without notable side effects on growing rabbits. Furthermore, it showed a significant positive effect on the physiology for treatment groups G3, G4 and G2 respectively compared to the control group.
\end{abstract}

Key words: Immunity, Lactobacillus acidophilus, Performance, Probiotic, Rabbit, Thyme oil

\section{INTRODUCTION}

Rabbits suffer from many digestive disorders related to cecal microflora, which cause high mortality and morbidity rates (Bäuerl et al., 2014). During the first growing period, changes in feeding behavior together with immature digestive and immune systems could promote the development of potentially pathogenic microflora, which could cause digestive troubles and reduce the performance parameters. In intensive rabbit farms, antibiotics are often added to feed or water for rabbits weaning till 8 weeks of age, in order to prevent enteric diseases (Cesari et al., 2008). The European Union banned the use of sub-therapeutic levels of antibiotics to prevent disease or promote growth. The European Union has already banned antibiotics on all remaining growth promoters (Delsol et al., 2005). Therefore, the searches for alternative feed supplements have been increased extensively and considerable attention has been given to the essential herbs as replacements for antibiotics growth promoters, which should have the same beneficial effect as antimicrobial growth promoters (AGPs). The most well-known mechanism to be proposed is that AGPs have an antibacterial action that favors performance through reducing the microbial use of nutrients and improving absorption of nutrients due to thinning of the intestinal wall. Probiotics have beneficially affected the host by boosting the properties of the indigenous microbiota (Huyghebaert et al., 2011). Probiotics can be used as treatment to improve feed intake and digestion (Abd El-Hack et al., 2017). In addition, Markowiak and Śliżewska (2018) stated that probiotics maintain stimulation of intestinal microbiota and protection in the intestine, which is important to combat pathogens for stimulation of immunological response and increased production capacity. The mechanism of action of probiotics includes establishing and maintaining healthy gut microflora, improving digestion and utilization of nutrients (Alagawany et al., 2018). Probiotics has a role in competitive exclusion of harmful bacteria/pathogens, decreases $\mathrm{pH}$, releases various antibacterial substances, neutralization of toxins, competition for nutrients with pathogens, reduction in ammonia production and stimulation of the immune system (Dhama et al., 2011). As feed additive, probiotics show a good impact on the rabbit performance in improving digestion, nutrient metabolism and utilization of nutrients by offering digestible proteins, vitamins, enzymes and other important 
co-factors and by decreasing the gut $\mathrm{pH}$ by production of lactic acids (Dhama et al., 2008). Also plant extracts have been considered as one of the important alternatives of antibiotics in animal production as Losa and Kohler (2001) reported a reduction of Clostridium perfringens in the intestine of poultry supplemented with a commercial preparation of essential oils in its diet. Taha et al., 2019 sated Clostridium difficile as an important pathogens causing diarrhea and enteritis in rabbits followed by intestinal damage and deaths. Marija et al. (2015) stated that essential oils obtained from plant extracts have antimicrobial and antioxidative activities. In addition, healthy and safe ingredients obtained from a variety of plant materials and have a strong antimicrobial effect. These oils are made from complex mixtures of volatile molecules that are produced by the secondary metabolism of aromatic and medicinal plants. It may perform its effect through disrupting the function of bacterial cell wall through affecting its lipopolysaccharides content leading to increase of the cell membrane permeability as reported by Faleiro (2011).

So, the aim of this study was to investigate the effect of using Lactobacillus acidophilus, Thyme oil and their mixture on performance and immune parameters and caecum characteristics in weaned rabbits. This additive can be perfect feeding rabbits by effect for maintain health and improve the growth of animals (Abdelnour et al., 2019; Alagawany et al., 2019).

\section{MATERIALS AND METHODS}

\section{Ethical approval}

All samples were collected as per standard procedure without giving any stress or harm to the animals and the study was conducted according to Cairo University Institutional Animal Care and Use Committee (CU- IACUC) Veterinary Medical and Agricultural Sciences Sector, Egypt under approval code \# CU/II/F/34/19\#.

\section{Experimental design}

A total number of 72 weaned V-Line male's rabbits, aged 30 days old with average body weight of $750 \pm 32 \mathrm{~g}$. were allocated randomly to four groups (18 rabbits each, which contains six replicates, 3 rabbits each replicate) and were treated as follows: The control group was without any additives in drinking water $(\mathrm{G} 1)$. The second group treated with Lactobacillus acidophilus $10^{8} \mathrm{cfu} /$ liter of drinking water $(\mathrm{G} 2)$. The third group treated with $1 \mathrm{ml}$ of thyme oil /liter of drinking water (G3). The fourth group treated with a mixture of Lactobacillus acidophilus $\left(10^{8} \mathrm{cfu} / \mathrm{ml}\right)$ and thyme (1 ml) per liter of drinking water (G4). Thyme oil was obtained from El- Gabry for natural herbs and medicinal plants belonging to El-Giza governorate, Egypt, and was tested for its active ingredients at Organic Pollutants department, Regional Center for Food and Feed, Agricultural Research Center, Giza, Egypt. Lactobacillus acidophilus strain was kindly supplied by Food Safety Department, Regional Center for Food and Feed, Agricultural Research Center, Giza, Egypt. Experimental diets were formulated to meet all the nutrient requirements of growing rabbits according to (De Blas, 1998) as showed in table 1. From Analysis of phenolic compounds in thyme oil analyzed by GC-MS/MS:The highest active ingredients of thyme oil (Thymol, Carvacrol) and Thymol compound appeared at the retention time (9.662 $\mathrm{min})$. While Carvacrol compound appeared at the retention time (10.172 $\mathrm{min})$ from data illustrated in figure1.

Table 1. Composition and chemical analysis of experimental diet of growing rabbits

\begin{tabular}{|c|c|}
\hline Ingredients & $\%$ \\
\hline Ground barley & 17.00 \\
\hline Wheat bran & 22.50 \\
\hline Yellow corn & 5.00 \\
\hline Soybean Meal (44\%) & 18.20 \\
\hline Straw & 8.00 \\
\hline Clover hay Alfalfa & 24.00 \\
\hline Di-calcium phosphate & 1.00 \\
\hline Limestone & 0.40 \\
\hline Methionine & 0.20 \\
\hline Salt & 0.40 \\
\hline Premix* & 0.30 \\
\hline Molasses & 3.00 \\
\hline \multicolumn{2}{|l|}{ Chemical analysis } \\
\hline Crude protein $(\%)$ & 17.88 \\
\hline Crude fiber $(\%)$ & 14.63 \\
\hline Ether extract (\%) & 2.68 \\
\hline Nitrogen free extract $(\%)$ & 49.21 \\
\hline Organic Matter $(\%)$ & 80.78 \\
\hline Digestible energy (Kcal/Kg) & 2568 \\
\hline
\end{tabular}




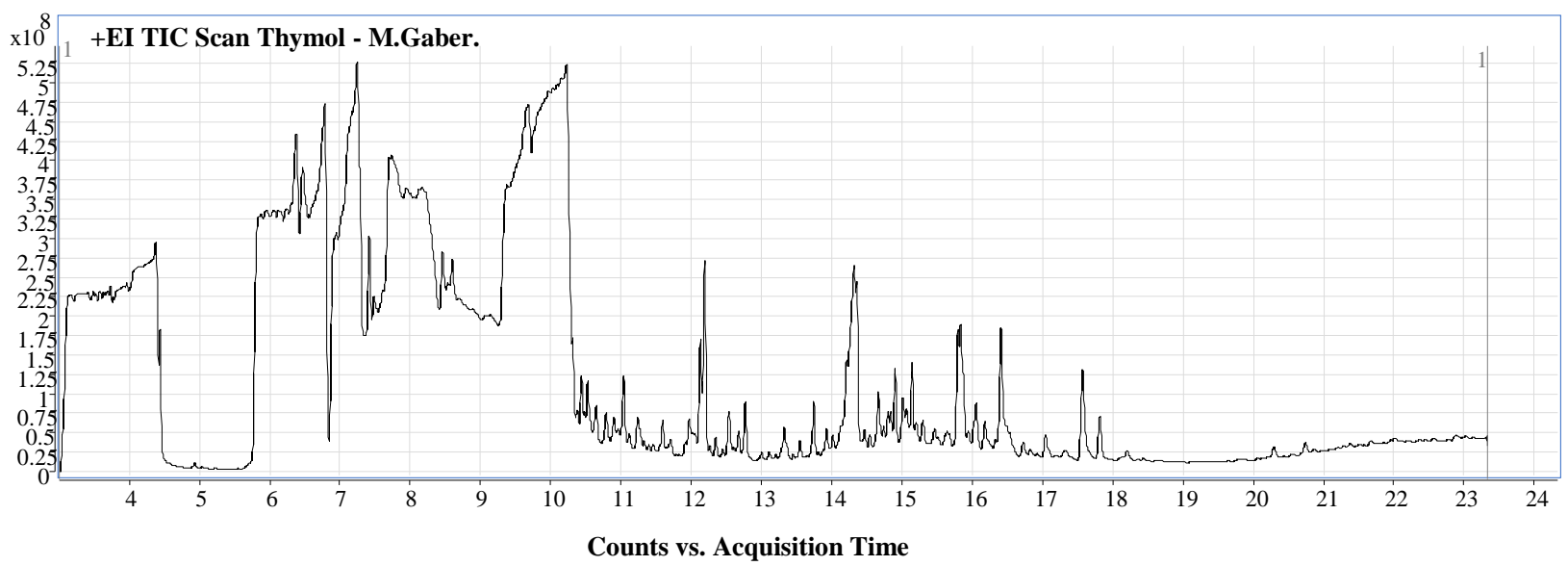

Figure 1. Chromatogram of used Thyme oil analyzed by GC-MS/MS instrument.

\section{Determination of thyme oil}

The active ingredients of thyme oil (Thymol, Carvacrol) were analyzed by GC-MS/MS according to Patricia et al. (2013). From data obtained in figure 1 it can be noticed that Thymol and Carvacrol are the most predominant ingredients in thyme oil composition as it represents about 13.71 and $23.22 \%$ respectively to all constituents as a peak area $\%$. These data were confirmed by the chromatogram illustrated in figure 1, which showed different intensities of the components represented by different levels of peaks. These data agreed with that reported by Karousou et al. (2005), Ortega-Nieblas et al. (2011) and Amiri (2012) who stated that Thymol and Carvacrol are the main components of thyme.

\section{Growth performance parameters}

Rabbits of all groups were kept under similar management conditions, diet and water were offered ad libidum during adaptation period (five days), after that diets were individually weighed for each group and feed residues were weighed daily and subtracted from the daily feed allowance to measure the actual daily feed intake (Table 1). Animals were individually weighed, weekly before offering the morning meal and continued for six weeks' period. The obtained weight was recorded as well as the consumed feed throughout the completely experimental period, which lasted for 6 weeks. The values of body weight, daily weight gain, daily feed intake, feed conversion ratio ( $g$ feed/ $g$ body weight) were recorded.

\section{Caecum characteristics}

After slaughtering, gastrointestinal tract was individually removed from six rabbits per each group, caecum content was collected and was taken to estimate microflora count under complete hygienic measures for determination of cecal microflora. The cecal appendix fluid was collected and estimation of cecum microflora was performed without any delay Lactobacillus acidophilus count and Enterococcus species count were measured by using a selective dehydrated media de Man Rogosa and Sharpe agar (MRS); Slantz and Bartly agar from (LabM a Neogen company, United Kingdom), respectively. Also, the microbial content was determined by using a selective dehydrated media Violet Red Bile agar (VRB); Brilliant Green agar was used to estimate E. coli count and Salmonella Spp count, respectively. Which can be summarized as follows: Ten-fold serial dilutions were performed from cecum content of each sample, and then $1 \mathrm{ml}$ from every dilution was inoculated into sterile petri dishes. Specific media of each targeted microorganism was poured into the inoculated petri dishes. The petri dishes were incubated as Lactobacillus acidophilus at $37{ }^{\circ} \mathrm{C}$ for 24 hours, Enterococcus species $44^{\circ} \mathrm{C}$ for 48 hours, E. coli $44^{\circ} \mathrm{C}$ for 24 hour and Salmonella Spp $37^{\circ} \mathrm{C}$ for 24 hours, before counting the bacteria.

Enumeration methods of Enterococcus species count was according to NMKL (2011), Lactobacillus acidophilus count was according to Soliman et al. (2015), Faecal coliform count was according to NMKL (2005) and Salmonella count was according to Gantois et al. (2008).

\section{Serum biochemical parameters}

Blood samples were collected after slaughtering of three rabbits per treatment into dry clean centrifuge tubes containing heparin and were centrifuged at $3000 \mathrm{rpm}$ for $15 \mathrm{~min}$. The plasma was collected and stored at $\left(-20^{\circ} \mathrm{C}\right)$ to estimate total protein, albumin, globulin, aspartate aminotransferase (AST), alanine aminotransferase (ALT), total cholesterol, LDL-, HDL-cholesterol, triglycerides, creatinine and glucose. These constituents were measured using commercial kits from (DiaSya Diagnostic, Germany) according to manufacturer's instructions.

Total protein was measured using Buiret method as described by Gornall et al. (1949). Albumin reacts with bromocresol green in alkaline solution and succinate buffer ( $\mathrm{pH} 4.2$ ). The produced colored complex was measured 
at $628 \mathrm{~nm}$ according to the method described by Doumas et al. (1971). Globulin (g/dl) was calculated as the difference between total protein content and albumin content of plasma. The aspartate aminotransferase (AST) and alanine aminotransferase (ALT) were measured by using the commercial kits from (DiaSya Diagnostic, Germany) according to the method that described by Reitman and Frankel (1957). Plasma alkaline phosphatase (ALP) was determined according to the modified methods of Kind and King (1954).

Total cholesterol estimation by quantitative enzymatic colorimetric determination of total cholesterol in serum or plasma according to Deeg and Ziegenhorn (1983). High density lipoprotein (HDL) was determined according to the method of Lopez-Virella et al. (1977). The plasma very low density lipoprotein cholesterol (VLDL) was estimated by the Friedewald formula (plasma triglycerides/5) as stated by Friedewald et al. (1972). The plasma low density lipoprotein cholesterol (LDL) was estimated by the Friedewald equation (LDL = Total cholesterol - High density lipoprotein cholesterol - triglycerides/5) as stated by Friedewald et al. (1972).

Triglyceride was determined in plasma according to Fossati and Prencipe (1982). Glucose was determined according to Trinder (1969). Creatinine was determined according to the method described by Bartels and Böhmer (1971). Plasma uric acid was measured according to Fawcett and Scott (1960). Serum hormones (T3, T4 and TSH) were determined by radioimmunoassay (RIA) according to Chopra et al. (1971); Wartofsky and Burman, (1982); Bolognani et al. (2001). The RBC's count analyzed by using hemocytometer according to Perkins (2009). The Hemoglobin was determined according to Van Kampen and Zillstra (1983). The Hematocrit was measured according to Bauer (1970). The WBC's count was determined by using hemocytometer according to Ewuola and Egbunike (2008). Determination of humeral immune response of Sheep Red Blood Cells (SRBC's) titer was according to the method of Van der Zijpp and Leenstra (1980).

\section{Determination of antioxidant markers}

Samples were collected from liver for each group, to determine (measure) the anti-oxidant markers. Malondialdehyde (MDA) was carried out according to the method of Mitsuru and Midori (1978). The reduced glutathione (GSH) was determined according to the method of Ellman (1959).

\section{Statistical analysis}

The data collected were statistically analyzed by General Linear Models (GLM) procedure of SAS program (SAS, 2004). During the experimental period according to the following statistical model:

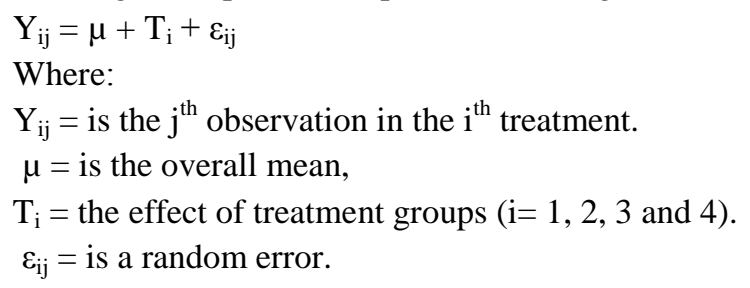

Significant differences among means were achieved using the Duncan of multiple range test (Duncan, 1955).

\section{RESULTS AND DISCUSSION}

\section{Growth performance}

Average live body weight affected by using thyme oil extract, probiotic and both as feed additives revealed that thyme had significantly the highest value of live body weight $(\mathrm{P}<0.05)$ when compared to the control group followed by the mixture between both thyme and Lactobacillus acidophilus then the used bacteria probiotic (Table 2). All obtained values significantly differed from each other. These results are consistent with Kritas and Morrison (2005) found that the beneficial effect of probiotic supplementation in broiler diet increased body weight. These results were significantly $(\mathrm{P}<0.05)$ in agreement with those obtained by de Lange et al. (2010) reported that essential oils improved the performance parameters not only by controlling enteric pathogens but also by increasing the palatability of the diet which can explain the body weight increase of rabbits in the present experiment.

As shown in table 2, all treatments significantly improved the body weight gain. The thyme group had the greatest effect followed by the mixture then the probiotic strain compared with the control. These results are consistent with Placha et al. (2013) explained that the highest weights for body weight gain achieved by thyme oil are usually associated with the protective effect by improving intestinal health. In addition, Shabaan (2012) reported that effect of Thymus vulgaris seeds improving the utilization of low energy broiler diet and accelerate body weight and all growth parameters in compared with control group. In addition, Chiofalo et al. (2004) reported that administration of probiotic strains separately and in combination was significantly improved daily weight gain and total body weight in chicken, sheep, and goat. Data obtained from table 2 showed the same trend during the experimental period on daily weight gain all over the experiment. It is clear that, at the end of the experiment, Thyme, mixture and Lactobacillus acidophilus had significant 
better effects on performance characteristics respectively if compared to the control group. There was a synergistic effect between essential oil and probiotics when use feed additives in poultry nutrition.

Table 2. The effect of Thyme oil and Lactobacillus acidophilus on performance characteristics of growing V-Line rabbits aged 72 days

\begin{tabular}{|c|c|c|c|c|c|}
\hline \multirow{2}{*}{ Characteristics } & \multirow{2}{*}{ Day old } & \multicolumn{4}{|c|}{ Treatments } \\
\hline & & G1 & G2 & G3 & G4 \\
\hline \multirow{3}{*}{$\begin{array}{l}\text { Average } \\
\text { Live Body Weight }\end{array}$} & (Initial)30 & $750 \pm 38.67$ & $751 \pm 28.65$ & $751 \pm 27.01$ & $751 \pm 33.35$ \\
\hline & 51 & $1320^{\mathrm{b}} \pm 39.72$ & $1361^{b} \pm 42.18$ & $1506^{\mathrm{a}} \pm 30.38$ & $1422^{\mathrm{ab}} \pm 46.77$ \\
\hline & 72 & $1850^{c} \pm 34.49$ & $1958^{\mathrm{b}} \pm 37.26$ & $2116^{\mathrm{a}} \pm 42.29$ & $2058^{\mathrm{ab}} \pm 31.02$ \\
\hline \multirow{3}{*}{ Body Weight Gain } & $30-51$ & $569^{c} \pm 13.28$ & $610^{c} \pm 23.89$ & $755^{\mathrm{a}} \pm 17.45$ & $671^{b} \pm 24.99$ \\
\hline & $52-72$ & $530^{\mathrm{b}} \pm 17.61$ & $597^{\mathrm{a}} \pm 20.51$ & $609^{\mathrm{a}} \pm 16.03$ & $636^{\mathrm{a}} \pm 12.90$ \\
\hline & $30-72$ & $1100^{\mathrm{d}} \pm 15.09$ & $1207^{\mathrm{c}} \pm 22.27$ & $1364^{\mathrm{a}} \pm 17.38$ & $1307^{\mathrm{b}} \pm 18.45$ \\
\hline \multirow{3}{*}{ Daily Weight Gain } & $30-51$ & $27.10^{c} \pm 0.63$ & $29.03^{c} \pm 1.14$ & $35.95^{\mathrm{a}} \pm 0.83$ & $31.97^{b} \pm 1.19$ \\
\hline & $52-72$ & $25.28^{\mathrm{b}} \pm 0.83$ & $28.45^{\mathrm{a}} \pm 0.97$ & $29.02^{\mathrm{a}} \pm 0.76$ & $30.28^{a} \pm 0.61$ \\
\hline & $30-72$ & $26.19^{d} \pm 0.35$ & $28.74^{\mathrm{c}} \pm 0.53$ & $32.49^{a} \pm 0.41$ & $31.13^{\mathrm{b}} \pm 0.43$ \\
\hline \multirow{3}{*}{ Feed Intake } & $30-51$ & $105^{\mathrm{a}} \pm 0.54$ & $86^{\mathrm{d}} \pm 0.31$ & $94^{\mathrm{b}} \pm 0.18$ & $91^{\mathrm{c}} \pm 0.38$ \\
\hline & $52-72$ & $138^{\mathrm{a}} \pm 0.74$ & $123^{\mathrm{d}} \pm 0.71$ & $126^{\mathrm{c}} \pm 0.67$ & $132^{\mathrm{b}} \pm 0.63$ \\
\hline & $30-72$ & $122^{\mathrm{a}} \pm 0.71$ & $104^{\mathrm{d}} \pm 0.31$ & $110^{\mathrm{c}} \pm 0.23$ & $112^{\mathrm{b}} \pm 0.44$ \\
\hline \multirow{3}{*}{ Feed Conversion Ratio } & $30-51$ & $3.92^{\mathrm{a}} \pm 0.09$ & $3.04^{\mathrm{b}} \pm 0.11$ & $2.65^{\mathrm{c}} \pm 0.06$ & $2.91^{\mathrm{bc}} \pm 0.1$ \\
\hline & $52-72$ & $5.58^{\mathrm{a}} \pm 0.18$ & $4.40^{\mathrm{b}} \pm 0.14$ & $4.40^{\mathrm{b}} \pm 0.1$ & $4.41^{b} \pm 0.09$ \\
\hline & $30-72$ & $4.67^{\mathrm{a}} \pm 0.07$ & $3.66^{\mathrm{b}} \pm 0.06$ & $3.41^{\mathrm{c}} \pm 0.03$ & $3.61^{\mathrm{b}} \pm 0.04$ \\
\hline
\end{tabular}

$\overline{\mathrm{a}-\mathrm{d}}$ Mean \pm SME in same row with different superscripts are significantly $(\mathrm{P}<0.05)$ different.G1 = control group; G2 = lactobacillus acidophilus; G3 = Thyme oil; G4= Mixture (lactobacillus acidophilus and Thyme oil); Significance $(\mathrm{P}<0.05)$; Non-Significant $(\mathrm{P}>0.05)$.

Data obtained from table 2 indicated the effect of the treatment at feed intake of the experimental animal during the study. All treatments significantly affected the feed intake values positively when compared to the control group the lowest consumed amount was recorded in group treated with Lactobacillus acidophilus followed by the group treated with Thyme. The group treated with the Mixture showed the third lowest consumed feed amount and the highest amount was recorded in the control group, through the whole duration of this study. Similar results were observed in other studies, Hertrampf (2001) reported that essential oils could be successfully used as growth promoters, by increasing the feed intake due to their aromatic characteristics in chickens. In addition, Chiofalo et al. (2004) reported that administration of probiotic strains separately and in combination was significantly improved feed intake, feed conversion rate in chicken, sheep and goat.

Data presented in table 2 showed that, the lowest FCR was recorded in group treated with thyme followed by the other two groups (Lactobacillus acidophilus and Mixture treated groups). While the value obtained in the control group was the highest indicated that, Thyme had the best effect on FCR followed by both Lactobacillus acidophilus and Mixture treated groups. This result was confirmed by those obtained by Lee et al. (2003) stated that components of essential oils, especially Carvacrol had a positive effect on FCR in broiler chickens. Also the Lactobacillus acidophilus were improved feed conversion for target species and benefits for the consumer through improved product quality, this agreement with those reported by Musa et al. (2009), So essential oils and Lactobacillus acidophilus had positive effects on FCR compared to control group in rabbit's diet.

\section{Cecum characteristics}

By studying the effect of the used treatments on caecum characteristics as an indicator of digestibility improvement, as a control approach for harmful bacteria and as a stimulant for beneficial bacteria, essential oils and probiotics had a positive effect on cecum of poultry and rabbits which caused increase performance parameters, which indicated better environment for the growth of the beneficial bacteria and unfavorable conditions for pathogenic bacteria in the cecum if compared to the control group this finding was confirmed by those reported by Bölükbaşi and Erhan (2007) found that $0.1 \%$ and $0.5 \%$ of thyme significantly reduced E. coli concentrations in the faeces of laying hens in treatments group compared with the control group, Also Cross et al. (2002) showed that thyme reduced the numbers of coliforms. And Simonová et al. (2010) indicated that diet enriched with some plant extracts is beneficial for the health rabbits. The antimicrobial activity in essential oils appears to be associated with phenolic compounds (Thymol and Carvacrol), these agreements with those reported by other authors (Karaman et al., 2001; Rota et al., 2008).

Mookiah et al. (2014) found Lactobacillus strains increased the caecal populations of Lactobacillus and decreased the caecal E. coli who stated that, essential oils and probiotics enhanced the growth of intestinal gram positive microflora and negatively affected the colonization of salmonella and E.coli due to increase of the acidity of the intertied content. Also, it was clear that all three treatments had the same positive effect on Lactobacillus and Enterococcus count (The highest number of colony forming units of the helpful bacteria was recorded in both groups which were treated with 
Lactobacillus and Mixture of Thyme and Lactobacillus while the cfu of the helpful bacteria was lower in the group treated with Thyme only). All treatments had significantly higher counts if compared to the count recorded in the control group. Concerning the effect of the used treatments on salmonella and E.coli, it was clear that, the bear effect was recorded in the groups treated with Thyme and mixture that showed the same significant effect followed by the effect of the added probiotic.

All treatments had a significant positive effect on the count of harmful bacteria if compared to the control group. Bölükbasi and Erhan (2007) clarified that essential oil and probiotics had stimulating effect on increasing beneficial bacteria which reduce the chances of growth and multiplication of harmful microbes that compete on the life and existence within the intestines by inhibition of harmful microbial growth. Also, in vitro studies have shown that essential oils to have antibacterial properties against Escherichia coli, Salmonella typhimurium that reported by Cosention et al. (1999).

Table 3. The effect of Thyme oil and Lactobacillus acidophilus on cecum characteristics of the growing V-Line rabbits aged 72 days

\begin{tabular}{|c|c|c|c|c|}
\hline \multirow{2}{*}{ Cecum bacterial count } & \multicolumn{3}{|c|}{ Treatments } & \multirow[b]{2}{*}{ G4 } \\
\hline & G1 & G2 & G3 & \\
\hline Lactobacillus acidophilus count $\left(\log _{10} \mathrm{cfu} / \mathrm{g}\right)$ & $4.4^{\mathrm{c}} \pm 0.17$ & $6.92^{\mathrm{a}} \pm 0.29$ & $5.69^{\mathrm{b}} \pm 0.29$ & $6.36^{\mathrm{ab}} \pm 0.14$ \\
\hline Enterococcus species count $\left(\log _{10} \mathrm{cfu} / \mathrm{g}\right)$ & $1.54^{\mathrm{c}} \pm 0.22$ & $3.58^{\mathrm{a}} \pm 0.08$ & $2.30^{\mathrm{b}} \pm 0.8$ & $3.22^{\mathrm{a}} \pm 0.07$ \\
\hline E. coli count $\left(\log _{10} \mathrm{cfu} / \mathrm{g}\right)$ & $4.39^{\mathrm{a}} \pm 0.07$ & $3.49^{\mathrm{b}} \pm 0.08$ & $2.58^{\mathrm{c}} \pm 0.29$ & $2.95^{\mathrm{c}} \pm 0.16$ \\
\hline
\end{tabular}

$\overline{a, b, c}$ Mean \pm SME in same row with different superscripts are significantly $(\mathrm{P}<0.05)$ different. $\left(\log _{10} \mathrm{cfu} / \mathrm{g}\right)$ the count of microbial colony-forming units (CFU) has expressed as logarithmic $\left(\log _{10}\right)$ transformation per gram of cecum contentG1 = control group; $\mathrm{G} 2$ = lactobacillus acidophilus; G3 = Thyme oil; G4= Mixture (lactobacillus acidophilus and Thyme oil); Significance $(\mathrm{P}<0.05)$; Non-Significant $(\mathrm{P}>0.05)$.

\section{Blood indices}

Data obtained from table 4 indicated that, all treatments had no significant effect on RBC'S, WBC'S, Hemoglobin and Hematocrit from the $30^{\text {th }}$ day to the $51^{\text {st }}$ day of age. These results supported present findings and reported by Chen et al. (2005) reported no significant effect of addition of probiotics on blood characteristics. While data obtained from table 4 during the $2^{\text {nd }}$ phase of the experiment (from $52^{\text {nd }}$ to $72^{\text {nd }}$ days of age), Thyme had the best effect on RBC'S count followed by Lactobacillus acidophilus while the mixture and the control group had lower values. All treatments showed the same significant positive effect on the count of WBC'S if compared to the control group and had no significant effect on neither hemoglobin nor hematocrits values. These results supported present findings and reported by Ezema and Eze (2012) stated that a significantly higher total WBC count in broiler rabbits fed diets supplemented with probiotics. Also Archetti et al. (2008) and Moore et al. (2015) reported that range of hemoglobin content (10.4 to $17.4 \mathrm{~g} / \mathrm{dl})$ in healthy growing rabbits.

Table 4. The effect of Thyme oil and Lactobacillus acidophilus on blood picture of the growing V-Line rabbits during the first and second period of experiment

\begin{tabular}{|c|c|c|c|c|c|}
\hline \multirow{2}{*}{ Day old } & \multirow{2}{*}{ Indices } & \multicolumn{4}{|c|}{ Treatments } \\
\hline & & G1 & G2 & G3 & G4 \\
\hline \multirow{4}{*}{51} & RBCs ( X10\% $/ \mathrm{uL})$ & $4.73 \pm 0.18$ & $4.90 \pm 0.08$ & $4.79 \pm 0.12$ & $4.74 \pm 0.16$ \\
\hline & $\mathrm{Hb}(\mathrm{g} / \mathrm{dl})$ & $10.96 \pm 0.30$ & $11.58 \pm 0.09$ & $11.23 \pm 0.26$ & $11.03 \pm 0.25$ \\
\hline & $\mathrm{Ht}(\%)$ & $31.06 \pm 0.63$ & $31.95 \pm 0.35$ & $31.73 \pm 0.65$ & $30.68 \pm 0.59$ \\
\hline & WBCs $\left(\mathrm{X} 10^{3} / \mathrm{uL}\right)$ & $6.33 \pm 0.53$ & $8.14 \pm 1.09$ & $6.79 \pm 0.75$ & $7.05 \pm 0.74$ \\
\hline \multirow{4}{*}{72} & RBCs (X10 $/ \mathrm{uL})$ & $4.60^{\mathrm{b}} \pm 0.15$ & $5.13^{\mathrm{ab}} \pm 0.45$ & $5.94^{\mathrm{a}} \pm 0.29$ & $4.80^{\mathrm{b}} \pm 0.18$ \\
\hline & $\mathrm{Hb}(\mathrm{g} / \mathrm{dl})$ & $12.10 \pm 0.27$ & $12.30 \pm 0.37$ & $11.85 \pm 0.32$ & $11.98 \pm 0.32$ \\
\hline & $\mathrm{Ht}(\%)$ & $31.70 \pm 0.66$ & $32.55 \pm 0.63$ & $31.48 \pm 0.74$ & $31.38 \pm 1.01$ \\
\hline & WBCs $\left(\mathrm{X} 10^{3} / \mathrm{uL}\right)$ & $4.75^{\mathrm{b}} \pm 0.21$ & $7.23^{\mathrm{a}} \pm 0.38$ & $7.52^{\mathrm{a}} \pm 0.56$ & $7.09^{\mathrm{a}} \pm 0.51$ \\
\hline
\end{tabular}

Through 72 day, ${ }^{\mathrm{a}, \mathrm{b}}$ Mean \pm SME in the same row with different superscripts are Significance $(\mathrm{P}<0.05)$. G1 = control group; G2 = lactobacillus acidophilus; G3 = Thyme oil; G4= Mixture (lactobacillus acidophilus and Thyme oil); Significance $(\mathrm{P}<0.05)$; Non-Significant $(\mathrm{P}>0.05)$.

\section{Blood Plasma constituents}

Studying the levels of TSH, $\mathrm{T}_{3}$ and $\mathrm{T}_{4}$ could clarify the immune response to the used treatments as it was clear from the data presented in table 5 that no marked significant effect was obtained on the levels of the three parameters during the first phase of the experiment (30-51 days of age). While during the second phase (52 to 72 days of age) that all treatments showed marked significant increase of $\mathrm{TSH}, \mathrm{T}_{3}$ and $\mathrm{T}_{4}$ when compared to the control group. It was noticed that, the treatments which contained live microorganisms (Lactobacillus acidophilus and the mixture) had better effect on T3, $\mathrm{T}_{4}$ and TSH values. This finding was similar to that obtained by Beisel (1982) that reported, nutrition plays an important role in the development and function of the immune system. In addition, Aluwong et al. (2012) indicated the effect of probiotics in thyroxin $\left(\mathrm{T}_{4}\right)$ level in broiler given feed supplemented with yeast. So, inclusion of living organisms could positively stimulate effects of TSH and consequently $\mathrm{T}_{3}$ and $\mathrm{T}_{4}$. 
Table 5. The effect of Thyme oil and Lactobacillus acidophilus on hormones indices, sheep red blood cells titer and liver antioxidant markers in growing V-Line.

\begin{tabular}{|c|c|c|c|c|c|}
\hline \multirow{2}{*}{ Day old } & \multirow{2}{*}{ Indices } & \multicolumn{4}{|c|}{ Treatments } \\
\hline & & G1 & G2 & G3 & G4 \\
\hline \multirow{3}{*}{51} & T3 (ng/dl) & $178.50 \pm 2.87$ & $183 \pm 7.51$ & $185.25 \pm 7.18$ & $182 \pm 9.26$ \\
\hline & T4 (ug/dl) & $3.75 \pm 0.33$ & $4.64 \pm 0.37$ & $4.48 \pm 0.31$ & $4.23 \pm 0.26$ \\
\hline & TSH (ulU/mL) & $0.33 \pm 0.11$ & $0.08 \pm 0.03$ & $0.11 \pm 0.03$ & $0.16 \pm 0.08$ \\
\hline \multirow{3}{*}{72} & T3 (ng/dl) & $174^{\mathrm{b}} \pm 12.53$ & $210^{\mathrm{a}} \pm 6.17$ & $208^{\mathrm{a}} \pm 6.68$ & $227^{\mathrm{a}} \pm 10.63$ \\
\hline & T4 (ug/dl) & $2.81^{\mathrm{c}} \pm 0.31$ & $3.55^{\mathrm{b}} \pm 0.17$ & $3.90^{\mathrm{ab}} \pm 0.08$ & $4.17^{\mathrm{a}} \pm 0.12$ \\
\hline & TSH (ulU/mL) & $0.12^{\mathrm{b}} \pm 0.03$ & $0.29^{\mathrm{ab}} \pm 0.07$ & $0.29^{\mathrm{ab}} \pm 0.08$ & $0.37^{\mathrm{a}} \pm 0.08$ \\
\hline 72 & Sheep RBC's titer & $2.50^{\mathrm{c}} \pm 0.29$ & $4.0^{\mathrm{b}} \pm 0$ & $4.25^{\mathrm{ab}} \pm 0.25$ & $5.25^{\mathrm{a}} \pm 0.63$ \\
\hline \multirow{2}{*}{72} & Malondialdehyde (MDA) (nM/gwet. tissue) & $10.98^{\mathrm{a}} \pm 0.8$ & $9.20^{\mathrm{ab}} \pm 0.9$ & $6.66^{\mathrm{c}} \pm 0.13$ & $8.34^{\mathrm{bc}} \pm 0.67$ \\
\hline & Reduced Glutathione(GSH) (mM/gwet. tissue) & $2.61^{\mathrm{b}} \pm 0.21$ & $4.05^{\mathrm{a}} \pm 0.30$ & $3.73^{\mathrm{a}} \pm 0.29$ & $3.77^{\mathrm{a}} \pm 0.25$ \\
\hline
\end{tabular}

$=$ Thyme oil; G4= Mixture (lactobacillus acidophilus and Thyme oil); Significance $(\mathrm{P}<0.05)$; Non-Significant $(\mathrm{P}>0.05)$.

Table 6. The effect of Thyme oil and Lactobacillus acidophilus on some blood parameters of the growing V-Line rabbits during the first and second period of experiment

\begin{tabular}{|c|c|c|c|c|c|}
\hline \multirow[b]{2}{*}{ Day old } & \multirow[b]{2}{*}{ Parameters } & \multicolumn{3}{|c|}{ Treatments } & \multirow[b]{2}{*}{ G4 } \\
\hline & & G1 & G2 & G3 & \\
\hline \multirow{14}{*}{51} & Total Protein $(\mathrm{g} / \mathrm{dl})$ & $9.46^{\mathrm{a}} \pm 0.93$ & $6.51^{\mathrm{b}} \pm 0.24$ & $7.78^{\mathrm{ab}} \pm 0.62$ & $7.56^{\mathrm{ab}} \pm 0.44$ \\
\hline & Albumin (g/dl) & $3.00 \pm 0.06$ & $3.00 \pm 0.06$ & $2.95 \pm 0.05$ & $3.06 \pm 0.04$ \\
\hline & Globulin (g/dl) & $6.46^{\mathrm{a}} \pm 0.88$ & $3.52^{\mathrm{b}} \pm 0.24$ & $4.83^{\mathrm{ab}} \pm 0.67$ & $4.50^{\mathrm{b}} \pm 0.44$ \\
\hline & Triglycerides (mg/dl) & $73.0 \pm 3.41$ & $67.33 \pm 3.17$ & $81.00 \pm 6.01$ & $69.67 \pm 8.50$ \\
\hline & Total cholesterol (mg/dl) & $60.0^{\mathrm{ab}} \pm 1.54$ & $63.33^{\mathrm{a}} \pm 1.78$ & $59.50^{\mathrm{ab}} \pm 3.01$ & $53.83^{\mathrm{b}} \pm 3.62$ \\
\hline & HDL $\quad(\mathrm{mg} / \mathrm{dl})$ & $26.17 \pm 0.98$ & $29.98 \pm 1.86$ & $27.73 \pm 1.67$ & $26.10 \pm 2.53$ \\
\hline & VLDL (mg/dl) & $14.60 \pm 0.68$ & $13.47 \pm 0.63$ & $16.20 \pm 1.20$ & $13.93 \pm 1.70$ \\
\hline & $\mathrm{LDL}(\mathrm{mg} / \mathrm{dl})$ & $19.23^{\mathrm{ab}} \pm 1.17$ & $19.88^{\mathrm{a}} \pm 0.82$ & $15.57^{\mathrm{ab}} \pm 2.83$ & $13.80^{\mathrm{b}} \pm 1.55$ \\
\hline & Glucose (mg/dl) & $95.16 \pm 6.76$ & $81.33 \pm 4.97$ & $105.67 \pm 12.82$ & $101.33 \pm 7.87$ \\
\hline & Urea $(\mathrm{mg} / \mathrm{dl})$ & $37.33^{\mathrm{a}} \pm 1.33$ & $29.83^{\mathrm{b}} \pm 1.07$ & $26.16^{\mathrm{b}} \pm 1.75$ & $26.50^{\mathrm{b}} \pm 1.25$ \\
\hline & Creatinine $(\mathrm{mg} / \mathrm{dl})$ & $0.62 \pm 0.03$ & $0.58 \pm 0.04$ & $0.53 \pm 0.02$ & $0.53 \pm 0.03$ \\
\hline & Alkaline phosphatase(U/L) & $220.16^{\mathrm{b}} \pm 26.42$ & $270.33^{\mathrm{ab}} \pm 40.46$ & $335.50^{\mathrm{a}} \pm 31.34$ & $311.83^{\mathrm{ab}} \pm 23.99$ \\
\hline & AST (U/L) & $39.33 \pm 6.42$ & $36.83 \pm 2.98$ & $31.50 \pm 3.91$ & $34.83 \pm 3.41$ \\
\hline & $\operatorname{ALT}(\mathrm{U} / \mathrm{L})$ & $21.67 \pm 2.53$ & $23.50 \pm 3.41$ & $26.50 \pm 3.88$ & $21.00 \pm 1.31$ \\
\hline \multirow{14}{*}{72} & Total Protein $(\mathrm{g} / \mathrm{dl})$ & $6.93^{\mathrm{a}} \pm 0.43$ & $6.62^{\mathrm{ab}} \pm 0.25$ & $5.70^{\mathrm{b}} \pm 0.32$ & $6.65^{\mathrm{ab}} \pm 0.14$ \\
\hline & Albumin (g/dl) & $3.88 \pm 0.19$ & $3.50 \pm 0.28$ & $3.75 \pm 0.09$ & $3.85 \pm 0.09$ \\
\hline & Globulin (g/dl) & $3.05^{\mathrm{a}} \pm 0.29$ & $3.11^{\mathrm{a}} \pm 0.28$ & $1.95^{\mathrm{b}} \pm 0.27$ & $2.80^{\mathrm{a}} \pm 0.18$ \\
\hline & Triglycerides (mg/dl) & $78.16^{\mathrm{a}} \pm 3.86$ & $61.16^{\mathrm{b}} \pm 4.48$ & $75.33^{\mathrm{ab}} \pm 2.78$ & $75.16^{\mathrm{ab}} \pm 6.85$ \\
\hline & Total cholesterol (mg/dl) & $62.67^{\mathrm{a}} \pm 1.54$ & $53.83^{\mathrm{ab}} \pm 3.28$ & $53.50^{\mathrm{b}} \pm 1.85$ & $60.67^{\mathrm{b}} \pm 2.82$ \\
\hline & HDL $(\mathrm{mg} / \mathrm{dl})$ & $31.85 \pm 3.04$ & $30.42 \pm 3.86$ & $29.23 \pm 2.45$ & $32.57 \pm 2.73$ \\
\hline & VLDL (mg/dl) & $15.63^{\mathrm{a}} \pm 0.77$ & $12.23^{\mathrm{b}} \pm 0.89$ & $15.06^{\mathrm{ab}} \pm 0.55$ & $15.03^{\mathrm{ab}} \pm 1.37$ \\
\hline & LDL $\quad(\mathrm{mg} / \mathrm{dl})$ & $15.18 \pm 3.10$ & $11.18 \pm 1.63$ & $9.20 \pm 2.18$ & $13.06 \pm 2.09$ \\
\hline & Glucose $(\mathrm{mg} / \mathrm{dl})$ & $140.50 \pm 8.20$ & $144.33 \pm 12.56$ & $129.50 \pm 7.32$ & $120.00 \pm 4.74$ \\
\hline & Urea $(\mathrm{mg} / \mathrm{dl})$ & $39.50^{\mathrm{a}} \pm 5.30$ & $28.66^{\mathrm{b}} \pm 1.56$ & $23.83^{\mathrm{b}} \pm 0.80$ & $22.00^{\mathrm{b}} \pm 0.36$ \\
\hline & Creatinine $(\mathrm{mg} / \mathrm{dl})$ & $0.87^{\mathrm{a}} \pm 0.03$ & $0.53^{\mathrm{b}} \pm 0.03$ & $0.52^{\mathrm{b}} \pm 0.01$ & $0.45^{\mathrm{b}} \pm 0.02$ \\
\hline & Alkaline phosphatase (U/L) & $132.67 \pm 15.88$ & $142.50 \pm 21.86$ & $113.33 \pm 4.97$ & $130.83 \pm 13.08$ \\
\hline & $\operatorname{AST}(\mathrm{U} / \mathrm{L})$ & $28.33 \pm 3.53$ & $23.16 \pm 5.08$ & $19.83 \pm 2.98$ & $20.33 \pm 2.70$ \\
\hline & ALT (U/L) & $38.33 \pm 3.90$ & $33.0 \pm 7.69$ & $35.67 \pm 2.82$ & $27.33 \pm 2.26$ \\
\hline
\end{tabular}

${ }^{\mathrm{a}, \mathrm{b}}$ Mean \pm SME in the same row with different superscripts are significantly $(\mathrm{P}<0.05)$ different.G1 = control group; G2 = lactobacillus acidophilus; G3 = Thyme oil; G4= Mixture (lactobacillus acidophilus and Thyme oil); Significance $(\mathrm{P}<0.05)$; Non-Significant $(\mathrm{P}>0.05)$.

With compared to the control group all treatments had a stimulation of immune system as represented by the positive effect on the sheep RBC'S titer that indicated the stimulation of immune system as an indicator for immunity and capability controlling pathogenic bacteria as shown in table 5. The G4 and G3 groups were higher (5.25 and 4.25; $\mathrm{P}<0.05)$ than those found in G2 and G1 groups (4.0 and 2.50) respectively, these data are in agreement with El-Sissi and Mohamed (2011) reported that, Lactobacillus improved the antibody response to NDV and IBV vaccines, as an indicator of immunity for animals.

Data obtained in table 5 indicated that all used treatment caused significant reduction of MDA levels, while the level of GSH in the seam of individuals in all treated groups shows significant increase when compared to the control group, these findings were according to with findings of Hashemipour et al. (2013) that reported Thymol improved 
antioxidant enzyme activities, and immune response. Also, Carvacrol, which play a role in raising the level of GSH, could decrease MDA which reported by Luaibi and Mousa. (2016). In addition, Kogan et al. (2008) reported that probiotics may have antioxidant activity. These results supported present findings and reported by Baratta et al. (1998) stated that thymol and carvacrol, which are the main components of thyme oil, showed strong antioxidative properties. These results showed that MDA that is one of the final products of polyunsaturated fatty acids peroxidation antioxidant activity of both probiotics and essential oils from plant exacts. In addition, GSH whose activity is to protect the organism from oxidative damage, increased as the effect of dietary probiotics and essential oils.

The table 6 showed that, all treatments caused no increase in some measured parameters which indicated no harmful negative effect on liver enzymes (ALT and AST), Glucose levels, Total protein, Albumin and Globulin. These results were agreed with those obtained with Onbasilar and Yalcin (2008) who stated that liver function tests (ALT and AST) were not affected by probiotics, Also these results disagree with those obtained with Tollba et al. (2010) that clarified the addition of aromatic herbal extract to the diets increased $(\mathrm{P}<0.05)$ total protein, albumin and globulin compared to control group under cold environmental temperature. However, except some measured parameters, it is clear from the same table 6 that, all treatments compared with the control group (G1) had significant reducing effect of kidney function parameters (Urea and Creatinine), Triglycerides and Total cholesterol as an indication of positive effect on the physiology of the experimental animals. These results were similar to the report of Shabaan (2012) who stated that broiler chicks fed the low energy diets supplemented with a mixture of $0.15 \%$ thyme and $0.15 \%$ cumin gave recorded lower values of plasma total protein, albumin and uric acid as compared to the control group. So, it is perceived both Thyme oil and Lactobacillus acidophilus had no harmful effect on liver function and blood protein. These data are in agreement with Lee et al. (2003) reported that, Thymol and Carvacrol have effects on growth performance and triglyceride metabolism in broiler chickens and reducing plasma triglyceride concentrations.

\section{CONCLUSION}

It was concluded that Thyme oil and Lactobacillus acidophilus can be used as feed additives as they had growth promoting effects and caused the improvement of performance and immunostimulant activity without notable side effects on growing rabbits. Studying the effect of Thyme oil by using ( $1 \mathrm{ml}$ of thyme oil /liter of drinking water) has the highest significant positive effect on body weight, body weight gain, daily weight gain and feed conversion ratio followed by the mixture of thyme oil and Lactobacillus acidophilus by using $10^{8} \mathrm{cfu} / \mathrm{ml}$ and thyme (1 ml) per liter of drinking water. Furthermore, a good positive effect on the physiology of the experimental animals compared with the control group.

\section{DECLARATIONS}

\section{Acknowledgments}

The authors are thankful to Prof. Dr. Ashraf Hashem "Director of the Regional Center for Food and Feed" for his support and assistance in the practical part. Deepest thanks are due to Prof. Dr. Nagwa Abdel-Hady Ahmed" Director of Rabbits Research and Development Unit" for facilitating the research work at this unit at the Faculty of Agriculture, Cairo University.

\section{Competing interests}

The authors declare that they have no conflict of interest with respect to the research, authorship, and/or publications of this article. The authors declare that they have no competing interests.

\section{Author's contribution}

Ahmed M. El-kaiaty and Gihan M. El-Moghazy they designed the experiment and laboratory analyses. Ahmed M. El-kaiaty designed article writing, revision and approval, Gihan M. El-Moghazy designed tabulation of experimental data, manuscript writing, commenting and approval, Mohamed A.F. El-Manylawi helped in statistical analysis, tabulation of experimental data and article revision; while, Mahmoud G.Y. Abdel-Mageed helped in field study, collected data, laboratory analyses, statistical analysis, manuscript writing. All authors have read and approved the final manuscript.

\section{REFERENCES}

Abd El-Hack ME, Mahgoub SA, Alagawany M and Ashour EA (2017). Improving productive performance and mitigating harmful emissions from laying hen excreta via feeding on graded levels of corn DDGS with or without Bacillus subtilis probiotic. Journal of Animal Physiology and Animal Nutrition, 101(5): 904-913. DOI: https://doi.org/10.1111/jpn.12522

Abdelnour SA, Abd El-Hack ME, Alagawany M, Farag MR and Elnesr SS (2019). Beneficial impacts of bee pollen in animal production, reproduction and health. Journal of Animal Physiology and Animal Nutrition, 103(2): 477-484. DOI: https://doi.org/10.1111/jpn.13049

Alagawany M, Abd El-Hack ME, Farag MR, Sachan S, Karthik K and Khama K (2018). The use of probiotics as eco-friendly alternatives for antibiotics in poultry nutrition. Environmental Science and Pollution Research, 25: 10611-10618. DOI: https://doi.org/10.1007/s11356-018$1687-\mathrm{x}$ 
Alagawany M, Elnesr SS, Farag MR, Abd El-Hack ME, Khafaga AF, Taha AE and Dhama K (2019). Omega-3 and Omega-6 fatty acids in poultry nutrition: Effect on production performance and health. Animals, 9(8): 573. DOI: https://doi.org/10.3390/ani9080573

Aluwong T, Raji MA, Hassan BF, Kawu MU, Kobo PI and Ayo JO (2012). Effect of different levels of supplemental Yeast on performance indices and serum biochemistry of broiler chickens. The Open Conference Proceedings Journal, 3 (Suppl 1-M7): 41-45. DOI: http://dx.doi.org/10.2174/1876326X01203020041

Amiri H (2012). Essential oils composition and antioxidant properties of three thymus species. Evidence-Based Complementary and Alternative Medicine. DOI: https://doi.org/10.1155/2012/728065

Archetti I, Tittarelli C, Cerioli M, Brivio R, Grilli G and Lavazza A (2008). Serum chemistry and hematology values in commercial rabbits: preliminary data from industrial farms in northern Italy. In Proceedings of 9th World Rabbit Congress, Italy (pp. 1147-1151). Available at: http://www.world-rabbit-science.com/WRSA-Proceedings/Congress-2008-Verona/Papers/W-Archetti.pdf

Baratta MT, Dorman HJD, Deans SG, Biondi DM and Ruberto G (1998). Chemical composition, antimicrobial and antioxidant activity of laurel, sage, rosemary, oregano and coriander essential oils. Journal of Essential Oil Research, 10: 618-627. DOI: https://doi.org/10.1080/10412905.1998.9700989.

Bartels H and Böhmer M (1971). Micro-determination of creatinine. Clinica Chimica Acta, 32: 81-85. DOI: https://doi.org/10.1016/00098981(71)90467-0

Bäuerl C, Collado MC, Zuniga M, Blas E and Martínez GP (2014). Changes in cecal microbiota and mucosal gene expression revealed new aspects of epizootic rabbit enteropathy. PLOS One, 9(8):e105707. Doi: https://dx.doi.org/10.1371\%2Fjournal.pone.0105707

Brennan J, Skinner J, Barnum DA and Wilson J (2003). The efficacy of bacitracin methylene disalicylate when fed in combination with narasin in the management of necrotic enteritis in broiler chickens. Poultry Science, 82:360-363. DOI: https://doi.org/10.1093/ps/82.3.360

Bauer JD (1970). Numerical evaluation of red blood, white blood cells and platelets, part $\amalg$, hematology. In: Clinical laboratory methods and diagnosis. $7^{\text {th }}$ Ed. The CV. Mosby. Co., Saint Louis, USA. (Frankel, S.; Reitman, S. and Somen Wirth, A. C. Editors).

Beisel W R (1982). Single nutrients and immunity. American Journal of Clinical Nutrition, 35:417-468. DOI: https://doi.org/10.1093/ajcn/35.2.417.

Bolognani F, Goya RG and Ronderos JR (2001). Thyroid-stimulating hormone and growth hormone release alterations induced by mosquito larvae proteins on pituitary cells, Cell Biology International, 25(9): 885-892. DOI: https://doi.org/10.1006/cbir.2001.0716

Bölükbaşi ŞC and Erhan MK (2007). Effect of dietary thyme (Thymus vulgaris) on Laying Hens performance and Escherichia coli (E. coli) concentration in feces. International Journal of Natural and Engineering Sciences. 1(2):55-58. Available at: http://agris.fao.org/agrissearch/search.do?recordID=TR2007000095

Cesari V, Toschi I, Pisoni AM, Grilli G and Cesari N (2008). Effect of dietary acidification on growth performance and caecal characteristics in rabbits. In Proc.: ${ }^{9}$ th World Rabbit Congress, June (pp.10-13). Available at: http://www.world-rabbit-science.com/WRSA-Proceedings/Congress2008-Verona/Papers/N-Cesari.pdf

Chen YJ, Son KS, Min BJ, Cho JH, Kwon OS and Kim IH (2005). Effects of Dietary probiotic on Growth Performance, Nutrients Digestibility, Blood Characteristics and Fecal Noxious Gas Content in Growing pigs. Asian-Australasian Journal of Animal Sciences. 18 (10): 1464-1468. DOI: https://doi.org/10.5713/ajas.2005.1464

Chiofalo V, Liotta L and Chiofalo B (2004). Effect of the administration of Lactobacilli on body growth and on the metabolic profile in growing Maltese goat Kids. Reproduction Nutrition Development, 44:449-457. DOI: https://doi.org/10.1051/rnd:2004051

Chopra J, Solomon DH and Bell GN (1971). Radioimmunoassay for Measurement of Trirodothyronine in Human Serum. Journal of Clinical Investigation, 50(10): 2033-2041. DOI: https://doi.org/10.1172/jci106696

Cosentino S, Tuberoso CIG, Pisano B, Satta M, Mascia V, Arzedi E and Palmas F (1999). In vitro antimicrobial activity and composition of Sardinian Thymus essential oils. Letters in Applied Microbiology, 29:130-135. DOI: https://doi.org/10.1046/j.1472-765x.1999.00605.x

Cross DE, Svoboda K, Hillman K, Mcdevitt R and Acamovic T (2002). Effects of Thymus vulgaris L. Essential oil as an in vivo dietary supplement on chicken intestinal microflora. Proceedings of the 33rd International Symposium on Essential Oils, Lisbon, Portugal, 3-7th Sept.

De Blas C (1998). Feed formulation. In: The Nutrition of the Rabbit, (Eds. De Blas, C. and Wiseman, J.), CABI, London, pp. 241-253.

Deeg R and Ziegenhorn J (1983). Kinetic enzymic method for automated determination of total cholesterol in serum. Clinical chemistry, 29(10): 17981802. DOI: https://doi.org/10.1093/clinchem/29.10.1798

De Lange CFM, Pluske J, Gong J and Nyachoti CM (2010). Strategic use of feed ingredients and feed additives to stimulate gut health and development in young pigs. Livestock Science, 134: 124-134. DOI https:// doi.org/10.1016/j.livsci.2010.06.117

Delsol AA, Randall L, Cooles S, Woodward MJ, Sunderland J and Roe JM (2005). Effect of the growth promoter avilamycin on emergence and persistence of antimicrobial resistance in enteric bacteria in the pig. Journal of Applied Microbiology, 98: 564-571. DOI: https://doi.org/10.1111/j.1365-2672.2004.02461.x

Dhama K, Verma V, Sawant PM, Tiwari R, Vaid RK and Chauhan RS (2011). Applications of probiotics in poultry: Enhancing immunity and beneficial effects on production performances and health-A review. Journal of Immunology and Immunopathology, 13(1): 1-19. Available at: http://www.indianjournals.com/ijor.aspx?target=ijor:jii\&volume=13\&issue $=1 \&$ article $=001$

Dhama K, Mahendran M, Tomar S and Chauhan RS (2008). Beneficial Effects of Probiotics and Prebiotics in Livestock and Poultry: The Current $\begin{array}{lllll}\text { Perspectives. } & \text { POLIVET, } & \text { 9(I):1-12. Available }\end{array}$ http://www.indianjournals.com/ijor.aspx?target=ijor:ipo\&volume=9\&issue=1\&article=001

Doumas BT, Watson WA and Biggs HG (1971). Albumin standards and the measurement of serum albumin with bromcresol green. Clinica Chimica Acta, 31:87-96. DOI: https://doi.org/10.1016/0009-8981(71)90365-2.

Duncan DB (1955). Multiple range and multiple F-tests. Biometrics, 11:1-42. Available at: https://www.jstor.org/stable/3001478

El-Sissi AF and Mohamed SH (2011). Impact of symbiotic on the immune response of broiler chickens against NDV and IBV vaccines. Global Journal of Biotechnology \& Biochemistry, 6(4):186-191. Available at: https://pdfs.semanticscholar.org/1d4f/5daeb1f6ea9a4910cc29d40c5d5fb8df3e4e.pdf

Ellman G (1959). Tissue sulfhydryl groups. Archives of Biochemistry and Biophysics, 82, 70-77. DOI: https://doi.org/10.1016/0003-9861(59)90090-6

Ewuola EO and Egbunike GN (2008). Hematological and serum biochemical response of growing rabbit bucks fed dietary fumonisin B1. African Journal of Biotechnology, 7: 430-4309. Available at: https://www.ajol.info/index.php/ajb/article/view/59575

Ezema C and Eze DC (2012). Determination of the effect of probiotic (Saccharomyces cerevisiae) on growth performance and hematological parameters of rabbits. Comparative Clinical Pathology, 21: 73-76. DOI: https://doi.org/10.1007/s00580-010-1066-6

Faleiro ML (2011). The mode of antibacterial action of essential oils. Science against microbial pathogens: communicating current research and technological advances A.Méndez-Vilas (Ed).p.1143-1156. Available at: https://www.academia.edu/download/37147183/EO.pdf

Fawcett JK and Scott J (1960). A rapid and precise method for the determination of urea. Journal of Clinical Pathology, 13(2): 156-159. DOI: https://doi.org/10.1136/jcp.13.2.156

Fossati P and Prencipe L (1982). Serum triglycerides determined calorimetrically with an enzyme that produces hydrogen peroxide. Clinical Chemistry, 28(10): 2077-2080. DOI: https://doi.org/10.1093/clinchem/28.10.2077 
Friedewald WT, Levy RI and Fredrickson DS (1972). Estimation of the concentration of low-density lipoprotein cholesterol in plasma without use of the preparative ultracentrifuge. Clinical Chemistry, 18: 499-502. DOI: https://doi.org/10.1093/clinchem/18.6.499

Gantois I, Eeckhaut V, Pasmans F, Haesebrouck F, Ducatelle R and Van Immerseel F (2008). A comparative study on the pathogenesis of egg contamination by different serotypes of Salmonella. Avian Pathology. 37(4), 399-406. DOI: https://doi.org/10.1080/03079450802216611

Gornall AG, Bardawill CJ and David MM (1949). Determination of serum proteins by means of the biuret reaction. Journal of Biological Chemistry, 177: 751-766. Available at: https://www.jbc.org/content/177/2/751.short

Hashemipour H, Kermanshahi H, Golian A and Veldkamp T (2013). Effect of thymol and carvacrol feed supplementation on performance, antioxidant enzyme activities, fatty acid composition, digestive enzyme activities and immune response in broiler chickens. Poultry Science, 92(8): 20592069. DOI: https://doi.org/10.3382/ps.2012-02685

Hertrampf JW (2001). Alternative antibacterial performance promoters. Poultry International, 40: 50-52. Available at: https://ci.nii.ac.jp/naid/10026253722/

Huyghebaert G, Ducatelle R and Immerseel F van (2011). An update on alternatives to antimicrobial growth promoters for broilers. The Veterinary Journal, 187: 182-188. DOI: https://doi.org/10.1016/j.tvj1.2010.03.003

Karaman S, Digrak M, Ravid U and Ilcim A (2001). Antibacterial and antifungal activity of the essential oils of Thymus revolutus Celak from Turkey. Journal of Ethnopharmacology, 76(2):183-186. DOI: https://doi.org/10.1016/S0378-8741(01)00238-0

Karousou R, Koureas DN and Kokkini S (2005). Essential oil composition is related to the natural habitats: Coridothymus capitatus and Satureja thymbra in NATURA 2000 sites of Crete. Phytochemistry, 66:2668-2673. DOI: https://doi.org/10.1016/j.phytochem.2005.09.020

Kind PRN and King EJ (1954). Estimation of plasma phosphatase by determination of hydrolysed phenol with amino-antipyrine. Journal of Clinical Pathology, 7: 322-326. DOI: http://dx.doi.org/10.1136/jcp.7.4.322

Kritas SK and Morrison RB (2005). Evaluation of probiotics as a substitute for antibiotics in a large pig nursery. Veterinary Record, 156 (14): $447-448$. DOI: http://dx.doi.org/10.1136/vr.156.14.447

Kogan G, Pajtinka M, Babincova M, Miadokova E, Rauko P, Slamenova D and Korolenko TA (2008). Yeast cell wall polysaccharides as antioxidants and antimutagens: Can they fight cancer? Neoplasma, 55:387-393. http://www.academia.edu/download/40207473/Yeast_cell_wall_polysaccharides_as_antio20151120-5133-wxizes.pdf

Lee KW, Everts H, Kappert HJ, Yeom, KH. and Beynen AC (2003). Dietary carvacrol lowers body weight gain but improves feed conversion in female broiler chickens. Journal of Applied Poultry Research, 12: 394-399. DOI: https://doi.org/10.1093/japr/12.4.394

Lopez-Virella MF, Stone P, Ellis S and Colwell JA (1977). Cholesterol determination in high-density lipoproteins separated by three different methods. Clinical Chemistry, 23:882-884. Available at: http://clinchem.aaccjnls.org/content/23/5/882.short

Losa R and Kohler B (2001). Prevention of colonisation of Clostridium perfringens in broilers intestine by essential oils. In: Proc. 13 ${ }^{\text {Th }}$ Eur. Symp. Poult. Nutr., Blankenberge, Belgium, p. 133.

Luaibi NM and Mousa AH (2016). A study effect of thyme on biochemical and histological changes in liver of male rats. Advances in Environmental Biology, 10(10): 217-227. Available at: https://pdfs.semanticscholar.org/75ad/d6260083ef5943c8f3f1713a4b578b0143df.pdf

Ortega-Nieblas MM, Robles-Burgueño MR, Acedo-Félix E, González-León A, Morales-Trejo A and Vázquez-Moreno L (2011). Chemical composition and antimicrobial activity of oregano (Lippia palmeri S.WATS) essential oil. Revista Fitotecnia Mexicana, 34 (1): 11 - 17. Available at: https://www.redalyc.org/pdf/610/61017038002.pdf

Onbasilar I and Yalcin S (2008). The effects of dietary supplementation of probiotic and anticoccidial additives on performance and blood parameters in growing rabbits. Revue de Médecine Vétérinaire, 159(11): 570-574. Available at: https://pdfs.semanticscholar.org/b3eb/78969e17b55af74e28916d5a9ba5c9fa31ad.pdf

Marija B, Nemanja Z, Jelena I, Jelena J, Jasna D, Marija S and Milan Z (2015). Antimicrobial activity of Thyme (Thymus vulgaris) and Oregano (Origanum vulgare) essential oils against some food-borne microorganisms. Journal of Procedia Food Science, 5:18-21. DOI https://doi.org/10.1016/j.profoo.2015.09.005

Markowiak P and Śliżewska K (2018). The role of probiotics, prebiotics and synbiotics in animal nutrition. Gut Pathogens, 10(1):21. DOI: https://doi.org/10.1186/s13099-018-0250-0

Mitsuru U and Midori M (1978). Determination of Malonaldhyde precursor in tissues by Thiobarbituric Acid Test. Analytical Biochemistry, 86(1): 271-278. DOI: https://doi.org/10.1016/0003-2697(78)90342-1

Mookiah S, Sieo CC, Ramasamy K, Abdullah N and Ho YW (2014). Effects of dietary prebiotics, probiotic and synbiotics on performance, caecal bacterial populations and caecal fermentation concentrations of broiler chickens. Journal of the Science of Food and Agriculture, 94: 341-348. DOI: https://doi.org/10.1002/jsfa.6365

Moore DM, Zimmerman K and Smith SA (2015). Hematological assessment in pet rabbits: blood sample collection and blood cell identification. Veterinary Clinics: Exotic Animal Practice, 18(1): 9-19. DOI: https://doi.org/10.1016/j.cvex.2014.09.003

Musa HH, Wu SL, Zhu CH, Seri HI and Zhu GQ (2009). The Potential Benefits of Probiotic in Animal Production and Health. Journal of Animal and Veterinary Advances, 8(2): 313-321.

Nordic-Committee on Food-analysis (NMKL) (2005). Thermotolerant coliform bacteria and Escherichia coli. Enumeration in food and feed. NMKL method No 125, 4th Ed., Oslo, Norway. Available at: https://www.nmkl.org/index.php/en/publications/item/termotolerante-koliforme-bakterierog-escherichia-coli-bestemmelse-i-naeringsmidler-og-for-nmkl-125-4-utg-2005

Nordic-Committee on Food-analysis (NMKL) (2011). Enumeration Enterococci in feed additives. NMKL method No.68, 5th Ed., Oslo, Norway. Available at: https://www.nmkl.org/index.php/en/publications/item/enterococcus-determination-in-foods-nmkl-68

Patricia MS, Migdalia M, Juan AP, Mario S, VÍctor H and Esther P (2013). Gas Chromatography- Mass Spectrometry Study from the Leaves Fractions Obtained of Vernonanthura patens (Kunth) H. Rob. International Journal of Organic Chemistry, 3: 105-109. DOI http://dx.doi.org/10.4236/ijoc.2013.32011

Perkins SL (2009). Examination of the Blood and Bone Marrow. In: Wintrobe's Clinical Hematology. 12 $2^{\text {th }}$ Ed. Lippincott Williams and Wilkins, Philadelphia, USA. Chapter 1. (Greer, J.P.; Foerster, J.; Roders, G.M.; Paraskevas, F.; Glader, B.; Arber, D.A. and Means Jr. RT. Editors).

Placha I, Chrastinova L, Laukova A, Cobanova K, Takacova J, Strompfova V, Formelova Z and Faix S (2013). Effect of thyme oil on small intestine integrity and antioxidant status, phagocytic activity and gastrointestinal microbiota in rabbits. Acta Veterinaria Hungarica, 61(2): 197-208. DOI: https://doi.org/10.1556/AVet.2013.012

Reitman S and Frankel S (1957). A colorimetric method for the determination of serum glutamic oxaloacetic and glutamic pyruvic transaminase. American Journal of Clinical Pathology, 28(1): 56-63. DOI: https://doi.org/10.1093/ajcp/28.1.56

Rota MC, Herrera A, Martinez RM, Sotomayor JA and Jordan MJ (2008). Antimicrobial activity and chemical composition of Thymus vulgaris, Thymus zygis and Thymus hyemalis essential oils. Food Control, 19(7): 681-687. DOI: https://doi.org/10.1016/j.foodcont.2007.07.007

SAS (2004). Statistical analysis system User's Guide: Statistics. Version 9.1. SAS Inst. Inc., Cary, North Carolina, USA.

Schneider BH and Flatt WP (1975). The evaluation of feed through digestibility experiments. University of Georgia Experiments. Univ. of Georgia Press Athens, Georgia, USA. P. 423. Available at: https://www.cabdirect.org/cabdirect/abstract/19761431484 
Shabaan M (2012). Effect of using thyme (Thymus vulgaris L) and cumin (Cuminum cyminum L) seeds for improving the utilization of low energy broiler diet. Egyptian Poultry Science Journal, $32 \quad$ (ш): https://pdfs.semanticscholar.org/5d95/dc0af95bc1cd484b07846f549cd4cf4fc0b3.pdf

Simonová MP, Chrastinová L, Mojto J, Lauková A, Szabóová R and Ján Rafay J (2010). Quality of rabbit meat and phyto-additives. Czech Journal of Food Sciences, 28(3):161-167. Available at: https://www.agriculturejournals.cz/publicFiles/49_2008-CJFS.pdf

Soliman AHS, Sharoba AM, Bahlol HEM, Soliman AS and Radi OMM (2015). Evaluation of Lactobacillus acidophilus, Lactobacillus casei and Lactobacillus plantarum for probiotic characteristics. Middle East Journal of Applied Sciences, 5 (1): 10 - 18. Available at: https://www.researchgate.net/publication/272564816

Taha MM, El-Helw HA, El-Sergany EF, El Sawy H, Abdella YA and El-Meneisy AA (2019). Identification of Locally Isolated Clostridium difficile from Rabbits. World Veterinary Journal, 9(1): 01-07. DOI: https://doi.org/10.36380/scil.2019.wvj1

Tollba AAH, Shabaan SAM and Abdel-Mageed MAA (2010). Effects of using aromatic herbal extract and blended with organic acids on productive and physiological performance of poultry 2 - The growth during cold winter stress. Egyptian Poultry Science Journal, 30 (1): $229-248$.

Van der Zijpp AJ and Leenstra FR (1980). Genetic Analysis of the Humoral Immune Response of White Leghorn Chicks. Poultry Science, 59:13631369. DOI: https://doi.org/10.3382/ps.0591363

Van Kampen EJ and Zijlstra WG (1983). Spectrophotometry of hemoglobin and hemoglobin derivatives. Advances in Clinical Chemistry, 23: 199257. DOI: https://doi.org/10.1016/S0065-2423(08)60401-1

Wartofsky L and Burman KD (1982). Alteration in thyroid function in patients with systemic illness: The 'Euthyroid sick syndrome'. Endocrine Reviews, 3(2): 164-217. DOI: https://doi.org/10.1210/edrv-3-2-164 